\title{
Increased biomass and salicylic acid elicitor activity in fennel (Foeniculum vulgare Miller)
}

\author{
Aumento de biomassa e atividade elicitora do ácido salicílico em funcho \\ (Foeniculum vulgare Miller)
}

\section{Pedro Henrique Gorni ${ }^{1 *}$, Matheus de Oliveira Brozulato², Renan da Silva Lourenção², Eliana Cristina Generoso Konrad ${ }^{2}$}

'Universidade do Oeste Paulista (UNOESTE), Presidente Prudente/SP - Brasil

${ }^{2}$ Centro Universitário de Adamantina (UniFAl), Adamantina/SP - Brasil

\author{
*Corresponding Author \\ Pedro Henrique Gorni, Universidade do Oeste Paulista (UNOESTE), Rodovia Raposo Tavares, km 572, CEP: 19067-175, Presidente Prudente/SP - \\ Brasil, e-mail:pgorni@gmail.com
}

Cite as: Increased biomass and salicylic acid elicitor activity in fennel (Foeniculum vulgare Miller). Braz. J. Food Technol., v. 20, e2016172, 2017.

Received: Dec. 02, 2016; Accepted: Apr. 17, 2017

\section{Abstract}

Fennel is a medicinal and aromatic plant that is commonly used in Brazilian cuisine and in the manufacture of cosmetics. The exogenous application of salicylic acid (SA) can act on the hormonal action stimulating plant growth and development and the induction of plant defense responses under stressful conditions. The objective of this study was to determine the effect of the foliar application of SA on the production of biomass and synthesis of secondary compounds in fennel plants. For this purpose, an experiment was carried out in potted plants in a greenhouse with the application of SA at concentrations of $0,0.25,0.50$ and $1.00 \mathrm{mM}, 20$ days and 90 days after transplanting the seedlings to the pots. The effect of SA on the metabolism of the fennel plants was evaluated using growth and biochemical parameters. The exogenous application of SA increased the plant shoots dry weight at the concentration of $0.50 \mathrm{mM}$, whereas an improved dry root mass and root/shoot ratio was achieved with the concentration of $0.25 \mathrm{mM}$. The elicitor effect was observed at $0.25 \mathrm{mM}$ of SA, resulting in greater economic value of the biomass due to the higher production of secondary compounds, such as phenolic compounds and flavonoids. In addition, an increase in antioxidant activity of the plant extracts and of the essential oil content of the species was obtained at the concentration of $1.00 \mathrm{mM}$.

Keywords: Fennel; Antioxidant activity; Phenolic compounds; Essential oil; Secondary metabolism.

\section{Resumo}

O funcho é uma planta medicinal, condimentar e ornamental, utilizada na culinária brasileira e na fabricação de cosméticos e de fitoterápicos. A aplicação exógena do ácido salicílico (AS) pode agir na ação hormonal, estimulando o crescimento e o desenvolvimento vegetal, e na indução das respostas de defesa das plantas. O objetivo deste trabalho foi determinar o efeito da aplicação foliar de AS sobre a produção de biomassa e a síntese de compostos secundários em plantas de funcho, uma espécie medicinal produzida comercialmente como matéria-prima para a indústria mundial de fitomedicamentos. O experimento foi conduzido em plantas envasadas em estufa, sem controle de umidade e temperatura. A aplicação do AS foi efetuada nas concentrações 0; 0,25; 0,50 e 1,00 mM, aos 20 dias e 90 dias após o transplante das mudas para os vasos. O efeito do AS sobre o metabolismo das plantas de funcho foi avaliado através de parâmetros biométricos de crescimento e bioquímicos. Conclui-se que a aplicação exógena de AS constitui-se em técnica de manejo vantajosa para a obtenção de aumento na biomassa das plantas de funcho: massa seca da parte aérea, na concentração de 0,50 mM, e massa seca de raízes e razão raiz/parte aérea, na concentração de 0,25 mM. O efeito elicitor foi obtido na concentração de $0,25 \mathrm{mM}$ de AS, resultando em maior valor econômico da matéria-prima, devido ao aumento na produção de compostos secundários, tais como fenóis totais e flavonoides, além de um concomitante aumento na atividade antioxidante do extrato vegetal e no teor do óleo essencial nesta espécie, na concentração de 1,00 mM.

Palavras-chave: Planta medicinal; Atividade antioxidante; Compostos fenólicos; Óleo essencial; Metabolismo secundário. 


\section{Introduction}

Foeniculum vulgare Miller (Apiaceae), known as fennel, is a medicinal species, native of Europe and widely cultivated throughout Brazil. It presents yellow flowers arranged in umbels and the fruits are deachenes (LORENZI; MATOS, 2002) and have carminative, digestive and diuretic properties. Fennel essential oil is used in the manufacture of liqueurs and perfumes and its seeds are used in confectionery as flavouring in breads, cakes and cookies. A key element to be considered in the cultivation of medicinal plants is the association of biomass production and plant quality as a raw material for the production of essential oil. Thus one must aim for optimum productivity, not just of biomass but also of the active ingredient that makes the plant a medicinal species (REIS et al., 2007).

Salicylic acid (SA) is a phenolic compound, considered as an important molecular flag in plants related to the plant defence response, which explains its role as a secondary metabolism elicitor. With respect to its elicitor activity, SA acts on the growth and development of the plant and, for this reason, is also regarded as a plant hormone (LIU et al., 2011). SA acts as a secondary messenger for the activation of defence genes under biotic and abiotic stress conditions. Several studies have shown that the exogenous application of SA can boost the growth and development of plants by acting on their signalling systems and inducing enzymes to catalyse the formation of defence compounds, which explains its role as a secondary metabolism elicitor, both in medicinal plants and in functional food species (GORNI; PACHECO, 2016). For example, SA induces the expression of genes related to the production of some classes of secondary metabolites in plants and activates phenylalanine ammonia-lyase (PAL), a key enzyme between the primary and secondary metabolism, involved in the phenylpropanoid compound production route of the secondary metabolism (DURRANT; DONG, 2004).

In wheat (Triticum aestivum L.), the foliar application of SA at concentrations as low as $0.001 \mathrm{mM}$ resulted in growth parameter increases (HAAS et al., 2015). Divya et al. (2014) studied the application of different levels of methyl jasmonate and salicylic acid on pre-harvest stages of coriander (Coriandrum sativum L.). Plants treated with $0.5 \mathrm{mM} \mathrm{SA}$ showed increases in the carotenoid and phenolic compound levels, besides additional increases in compounds such as chlorophyll and lutein. Yarrow (Achillea millefolium L.) treated with 0.50 and $1.00 \mathrm{mM}$ SA showed greater biomass accumulation, higher chlorophyll "a", total chlorophyll and total phenolic compound contents and greater antioxidant activity (GORNI; PACHECO, 2016).

The objective of this study was to determine the effect of foliar SA application on the production of biomass and synthesis of secondary compounds in fennel plants Foeniculum vulgare (Mill.), a medicinal species commercially produced as a raw material for the global phytomedicine industry.

\section{Material and methods}

The experiment was carried out in a greenhouse on wooden benches, open to the sky and covered by shading which provided $50 \%$ of solar radiation. The experiment was located in Salmourão (2137'27" S, 5051'38" W, 461 m.a.s.I.), São Paulo State, Brazil and the analyses were carried out in the Biochemistry Laboratory of the Centro Universitário de Adamantina - UniFAI, Adamantina, São Paulo State, Brazil.

Trademark fennel seeds were placed in a germination tray and after the training period (30 days), were planted in $8 \mathrm{~L}$ pots containing fallow soil with fertility levels adequate to support plant growth. The pots were irrigated twice daily at 8 a.m. and 5 p.m. in order to maintain the soil moist and ensure the availability of water throughout the experimental period.

Salicylic Acid (SA) was applied for 3 consecutive days 20 and 90 days after being transplanted to the pots. The different SA concentrations $(0 ; 0.25 ; 0.50$ and $1.00 \mathrm{mM})$ were sprayed onto the aerial parts with a hand-held sprayer until the suspension ran off in drops (approximately $40 \mathrm{~mL}$ per plant, with the addition of $50 \mu \mathrm{L} . \mathrm{L}^{-1}$ surfactant). The control plants were only sprayed with distilled water (1000 mL) mixed with ethanol $(10 \mathrm{~mL})$.

The plants were harvested 120 days after transplanting the seedlings by collecting the young and adult leaves. To determine the dry mass, the leaves were placed in an oven with air circulation at $40{ }^{\circ} \mathrm{C}$ until constant weight.

\subsection{Plant growth}

The effect of SA on the plants was evaluated using the following variables: total leaf area ( $\left.\mathrm{LA}-\mathrm{cm}^{2}\right)$, number of leaves per plant (NL), dry mass of leaves and roots ( $\mathrm{g} \mathrm{plant}^{-1}$ ) and biomass partitioning. The total leaf area (LA) was assessed using the ImageJ ${ }^{\circledR}$ Software (Powerful Image Analysis) with 6 plants per treatment. The number of leaves/plant was determined by manual counting, considering both young and adult leaves. The dry mass of leaves and roots was determined after drying in an oven with air circulation at $40{ }^{\circ} \mathrm{C}$ (leaves) and $60{ }^{\circ} \mathrm{C}$ (roots) to constant weight.

\subsection{Determination of Total Phenolic compound content}

The total phenolic compound content $\left(\mu \mathrm{g} \mathrm{mL}^{-1}\right)$ in the leaves was determined using the Folin-Ciocalteu method with gallic acid as the standard in a methanol / sodium carbonate solution (SINGLETON; ROSSI JUNIOR, 1965). 


\subsection{Determination of DPPH}

The antioxidant capacity was assessed from the free radical scavenging activity of 2,2-diphenyl-1-picrylhydrazyl (DPPH), as the amount of antioxidant required to reduce the initial concentration of DPPH by $50 \%$ (inhibitory concentration $-I_{50}$ ) (BRAND-WILLIAMS et al., 1995). The absorbance values at all concentrations tested were also converted to percentage of antioxidant activity (\% AA), as determined by the equation: $A A(\%)=\left[\left(A_{\text {control }}-A_{\text {sample }}\right) / A_{\text {control }}\right] \times 100$ (MOREIRA et al., 2005).

\subsection{Determination of total flavonoid content}

The total flavonoid content of the leaves was determined using quercetin as the standard in methanol and aluminium chloride (VERLAG, 1978), and was calculated from the calibration curve equation obtained by linear regression.

\subsection{Essential oil extraction}

The essential oil content (\%) and yield (g) were estimated by hydro-distillation in a Clevenger apparatus from a $10 \mathrm{~g}$ sample of dried leaves. The oil mass was obtained after removal of the salt (anhydrous magnesium sulphate) and evaporation of the solvent (dichloromethane), according to Brant et al. (2009).

\subsection{Statistical analysis}

The experiment was organized using a completely randomized design with 4 treatments (SA concentrations) and 10 repetitions (individuals) per treatment. The data were submitted to an analysis of variance $(p<0.05)$, and then to both regression analyses and the Tukey test (considering $p<0.05$ in all cases). ANOVA was applied to all the experimental data using the statistical programme ASSISTAT (SILVA, 2010), and the mean differences were assessed at the $5 \%$ level by Tukey's test.

\section{Results and discussion}

\subsection{Plant growth}

The application of SA promoted a significant increase in dry leaf mass (DLM) at a concentration of $0.50 \mathrm{mM}$ of $S A$ as compared to the control plants (Figure 1). In plants treated with $0.25 \mathrm{mM}$ of SA, the dry root mass (DRM) increased $17.5 \%$ when compared to the control plants. However, there was no difference between the treatments for total dry mass (TDM) after applying the different concentrations of $S A$. Plants with a greater root mass can benefit from a rise in water and nutrient absorption, which ultimately reverses the general improvement of the physiological processes of the plant (GORNI; PACHECO, 2016). Parashar et al. (2014), when studying Brassica juncea plants treated with $0.01 \mathrm{mM} \mathrm{SA}$, reported increments in dry root mass $(26 \%)$ and shoots $(51 \%)$, despite a reduction in leaf area.
The leaf area (LA), number of leaves $(\mathrm{NL})$ per plant and specific leaf area (SLA) of $F$. vulgare treated with SA were not significantly different between treatments (Table 1). Different results were found by Villanueva-Couoh et al. (2009) when studying the effects of applying SA in the growth of chrysanthemum plants. The authors reported a significant increase in the leaf area parameter for concentrations of $10^{-7} \mathrm{mM} \mathrm{SA}$ and $10^{-5} \mathrm{mM} \mathrm{SA}$. Concentrations of $0.01 \mathrm{mM}$ and $1.00 \mathrm{mM}$ of SA showed an increase in the NL per plant in basil (Ocimum basilicum) and marjoram (Origanum Majorana) (GHARIB, 2007). Specific leaf area represents the trade leaf investment in photosynthetic area at the expense of leaf thickness (CRAWLY, 2001).

The root / shoot ratio (RS) (Table 1) showed an increase of $37 \%$ at $0.25 \mathrm{mM} \mathrm{SA}$, corresponding to a greater accumulation of carbohydrates in the roots as compared to the leaves. The relationship between the dry masses of the roots and aerial parts expresses a functional balance between the photosynthetic rate and water absorption by the roots, which under the present conditions, showed the right balance (TAIZ; ZEIGER, 2013). Different results were found in maize plants treated with $20 \mathrm{mg} \mathrm{L}^{-1} \mathrm{SA}$ and $40 \mathrm{mg} \mathrm{L}^{-1} \mathrm{SA}$, in which lower root/shoot ratios were observed when compared with the untreated plants (AHMAD et al., 2015).

To the contrary, the ratio of leaf area/number of leaves (LANL) (Table 1) was statistically different at $1.00 \mathrm{mM} \mathrm{SA}$. Results obtained by Gorni and Pacheco (2016) showed that yarrow plants treated with different concentrations of SA did not differ between treatments with respect to the LANL parameter.

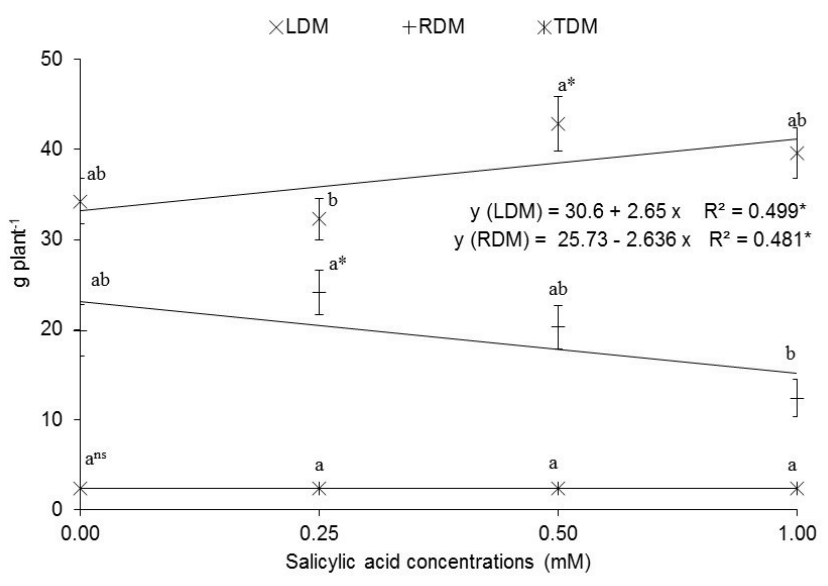

Figure 1. Determination of the dry leaf (DLM), root (DRM) and total (TDM) masses of F. vulgare plants treated with different concentrations of salicylic acid. Different letters indicate significant differences according to Tukey's test * $(p<0.05)$, ns (= not significant), $p$-values: $\mathrm{DLM}=0.0335, \mathrm{DRM}=0.0171$ and $\mathrm{TDM}=0.0886$. 
Increased biomass and salicylic acid elicitor activity in fennel (Foeniculum vulgare Miller)

Gorni, P. H. et al.

Table 1. Leaf area, number of leaves, specific leaf area, root/shoot dry mass ratio, leaf area/number of leaves and leaf mass values in F. vulgare plants treated with different concentrations of salicylic acid.

\begin{tabular}{cccc}
$\begin{array}{c}\text { Salicylic Acid } \\
(\mathbf{m M})\end{array}$ & $\begin{array}{c}\text { LA } \\
\left(\mathbf{c m}^{2}\right)\end{array}$ & NL & SLA \\
\hline 0.00 & $713.7661 \pm 142.9933^{\mathrm{ans}}$ & $6.8889 \pm 0.3333^{\mathrm{ans}}$ & $0.0201 \pm 0.0037^{\mathrm{ans}}$ \\
0.25 & $609.6903 \pm 91.3637^{\mathrm{a}}$ & $7.0000 \pm 0.7071^{\mathrm{a}}$ & $0.0216 \pm 0.0056^{\mathrm{a}}$ \\
0.50 & $700.0050 \pm 133.0302^{\mathrm{a}}$ & $6.7778 \pm 0.6667^{\mathrm{a}}$ & $0.0170 \pm 0.0028^{\mathrm{a}}$ \\
1.00 & $701.3913 \pm 146.7139^{\mathrm{a}}$ & $6.2222 \pm 1.3944^{\mathrm{a}}$ & $0.0202 \pm 0.0053^{\mathrm{a}}$ \\
Salicylic Acid & $\mathbf{R S}$ & $\mathbf{L A N L}$ & $\mathbf{L M}$ \\
$(\mathbf{m M})$ & $0.5124 \pm 0.0782^{\mathrm{ab}}$ & $109.6957 \pm 16.6711^{\mathrm{ab}}$ & $1.5659 \pm 0.2529^{\mathrm{ans}}$ \\
& $0.8135 \pm 0.1399^{\mathrm{a}}$ & $90.3582 \pm 5.3079^{\mathrm{b}}$ & $1.4227 \pm 0.1643^{\mathrm{a}}$ \\
0.25 & $0.4979 \pm 0.0721^{\mathrm{ab}}$ & $106.1386 \pm 24.6712^{\mathrm{ab}}$ & $1.3572 \pm 0.2279^{\mathrm{a}}$ \\
\hline 0.50 & $0.3439 \pm 0.0722^{\mathrm{b}}$ & $121.6683 \pm 15.0745^{\mathrm{a}}$ & $0.2837^{\mathrm{a}}$ \\
\hline 1.00 & & & \\
\hline
\end{tabular}

Different letters indicate significant differences according to Tukey's test * $(p<0.05)$ and ns ( $=$ not significant), $p$-values $(L A=0.4492, N L=0.2516$, $\mathrm{SLA}=0.4627, \mathrm{RS}=0.012, \mathrm{LANL}=0.0343, \mathrm{LM}=0.0722)$.

The leaf mass (LM) (Table 1) did not differ between the SA treatments. LM represents the photosynthetic translocation capacity of the aerial parts to other parts of the plant and the smaller the value, the more efficient is translocation, favouring an increase in plant growth, especially in diameter. The growth and development of cotton plants as a function of the SA dose was responsible for the highest value of the LM parameter (FARIAS, 2012).

\subsection{Essential oil}

The concentration of $1.00 \mathrm{mM}$ of SA resulted in a significant increase of $12.41 \%$ in the essential oil content as compared to the control plants (Figure 2). In agreement with the present work, Hashmi et al. (2012) evaluated fennel plants treated with $S A$, and showed that the application of $0.1 \mathrm{mM}$ SA resulted in significant increases in the essential oil content. However, the essential oil yield did not show a significant response to the SA treatments. The response of plants to SA may depend on the species, as observed by Gorni and Pacheco (2016), who observed that $0.50 \mathrm{mM}$ $S A$ resulted in a significant increase in the essential oil yield in yarrow plants.

\subsection{Total phenolic compound and flavonoid contents}

SA acts in plants as a biotic elicitor and can increase the production of different groups of secondary metabolites such as terpenes, alkaloids, flavonoids, phenolic compounds and phytoalexins (SILVA et al., 2014). The exogenous application of SA had a significant effect on the accumulation of total phenols (TP) in fennel, as shown by the quadratic relationship between the total phenolic content and the SA concentrations applied (Figure 3). The total phenolic compound contents of plants treated with $0.25 \mathrm{mM} \mathrm{SA}$ increased by $56.95 \%$ as compared to the control plants. These results corroborate those obtained by Gorni and Pacheco (2016) in yarrow plants treated with

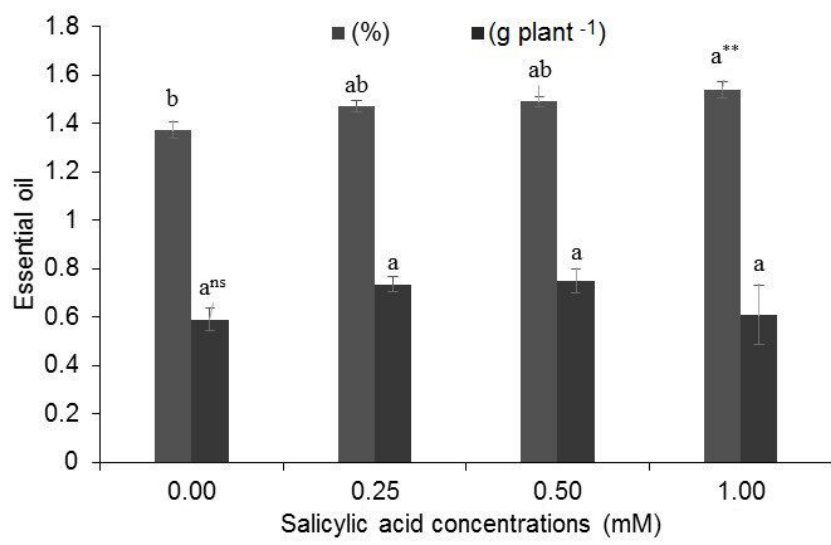

Figure 2. Essential oil content and yield in F. vulgare treated with different concentrations of salicylic acid. Different letters in each column indicate significant differences according to Tukey's test ${ }^{* \star}(p<0.01)$ and ns (= not significant $), p$-value: Content $=0.0084$, Yield $=0.3366$.

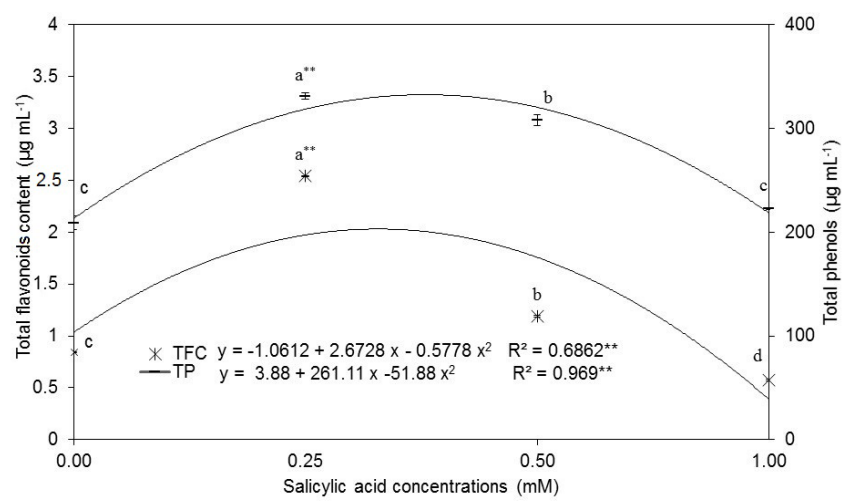

Figure 3. Total phenolic compound and total flavonoid contents of $F$. vulgare treated with different concentrations of salicylic acid. Different letters indicate significant differences according to Tukey's test ${ }^{* *}(p<0.01), p$-values: Total phenolic compounds $=0.0001$, Total flavonoids $=0.0001$. 
SA, which showed increases in total phenolic compound contents of $68.11 \%$ and $69.74 \%$ with SA concentrations of 0.50 and $1.00 \mathrm{mM}$, respectively.

The rise in total flavonoid contents (TFC) produced in fennel leaves reached a peak of $66.77 \%$ with the SA concentration of $0.25 \mathrm{mM}$ as compared to the control plants (Figure 3). Results found by Yoon et al. (2009) for the total flavonoid contents of Taraxacum officinale plants also showed significant increases in response to the application of $0.5 \mathrm{mM} \mathrm{SA}$ and $1.00 \mathrm{mM} \mathrm{SA}$, which demonstrates the relevant role of this substance on the biosynthesis of these secondary metabolites. In addition to the positive effect on production, SA promotes a higher economic value of the raw material, by increasing the flavonoid contents of the leaves.

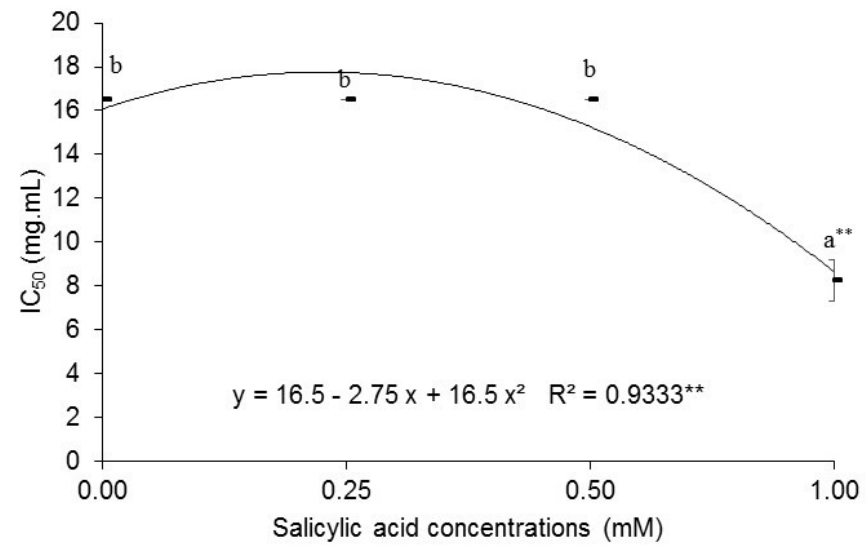

Figure 4. Antioxidant activity of F. vulgare treated with different concentrations of salicylic acid. Different letters indicate significant differences according to Tukey's test ${ }^{* *}(p<0.01), p$-value $(0.0001)$.

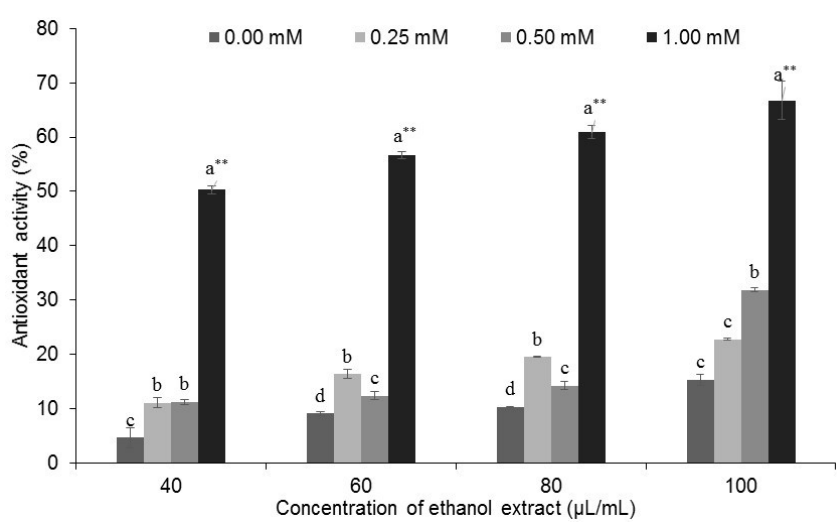

Figure 5. Percentage of antioxidant activity of the ethanol extracts of F. vulgare treated with different concentrations of salicylic acid. Different letters indicate significant differences between the salicylic acid concentrations for each extract concentration according to the Tukey test ${ }^{* *}(p<0.01)$, $p$-values: $(40=0.0001$, $60=0.0001,80=0.0001,100=0.0001)$.

\subsection{Antioxidant activity}

The antioxidant activity of the F. vulgare extract presented a significant decrease in the $\mathrm{IC}_{50}$ values of $100 \%$ with the application of $1.00 \mathrm{mM} \mathrm{SA}$ as compared to the control plants (Figure 4). These results agree with those obtained by Ghasemzadeh et al. (2012) with two varieties of Zingiber officinale treated with SA, which showed higher antioxidant activity with SA concentrations of $0.01 \mathrm{mM}$ and $1.00 \mathrm{mM}$. According to these authors, this effect can be attributed to the increase in phenolic compounds (such as flavonoids and hydroxycinnamic acids) in plants treated with SA, which are considered as the major antioxidant compounds in the plant.

The results presented in Figure 5 show that for all quantities of ethanol leaf extract there was no significant difference between the percentages of antioxidant activity for different SA concentrations. However, fennel plants treated with $1.00 \mathrm{mM}$ SA showed higher antioxidant activities for the same amounts of ethanol extract as compared to the control plants.

The cells have different mechanisms for maintaining redox homeostasis. Notable amongst these is the synthesis of phenolic compounds, known as potent inhibitors of oxidative stress (KOVÁCIK et al., 2009). Exogenous SA, even at low concentrations, interacts with the stress-signalling mechanisms (GORNI; PACHECO, 2016). Thus increases in the SA levels may trigger cell signalling that regulates the expression of genes encoding enzymes related to the phenylpropanoid pathway (including the total phenolic compounds, antioxidant activity, flavonoids). In turn, this may increase the activity of the enzymes involved in the production of secondary plant metabolites related to defence, such as phytoalexins and lignin (LA CAMERA et al., 2004).

Finally, medicinal plants are considered as alternative crops for diversification and a new source of income for family farming. The saleable products from $F$. vulgare are the leaves and seeds, which are sold to pharmaceutical companies and drugstores by weight and quality (phenolic compounds, essential oil and flavonoid contents). The present results showed that the foliar application of SA to fennel resulted in better plant growth and, consequently, higher production of the secondary metabolites of great interest in the production of herbal medicines.

\section{Conclusion}

The exogenous application of SA at concentrations of 0.25 to $0.50 \mathrm{mM}$ constituted an advantageous management technique to increase biomass production in fennel crops. Furthermore, this study showed that the elicitor effect obtained by the exogenous application of $\mathrm{SA}$ at the concentration of $0.25 \mathrm{mM}$ resulted in a better economic value of the biomass due to an increase in the production of secondary metabolites such as flavonoids 
Increased biomass and salicylic acid elicitor activity in fennel (Foeniculum vulgare Miller)

Gorni, P. H. et al.

and phenolic compounds. In addition, a concomitant increase in the antioxidant activity of the plant extracts and in the essential oil content of this species was achieved at a concentration of $1.00 \mathrm{mM} \mathrm{SA}$.

\section{References}

AHMAD, I.; BASRA, S. M. A.; HUSSAIN, S.; HUSSAIN, S. A.; REHMAN, H. U.; REHMAN, A.; ALI, A. Priming with ascorbic acid, salicylic acid and hydrogen peroxide improves seedling growth of spring maize at suboptimal temperature. Journal of Environmental \& Agricultural Sciences, Madison, v. 3, p. 14-22, 2015.

BRAND-WILLIAMS, W.; CUVELIER, M. E.; BERSET, C. Use of a free radical method to evaluate antioxidant activity. LWT - Food Science and Technology, London, v. 28, n. 1, p. 25-30, 1995. http://dx.doi.org/10.1016/S0023-6438(95)80008-5.

BRANT, R. S.; PINTO, J. E. B. P.; ROSA, L. F.; ALBUQUERQUE, C. J. B.; FERRI, P. H.; CORRÊA, R. M. Crescimento, teor e composição do óleo essencial de melissa cultivada sob malhas fotoconversoras. Ciência Rural, Santa Maria, v. 39, n. 5, p. 14011407, 2009. http://dx.doi.org/10.1590/S0103-84782009005000083.

CRAWLY, M. J. Plant ecology. In: CRAWLY, M. J. (Ed.). Oxford: Blackwell Science, 2001. 703 p.

DIVYA, P.; PUTHUSSERI, B.; NEELWARNE, B. The effect of plant regulators on the concentration of carotenoids and phenolic compounds in foliage of coriander. Food Science and Technology, Campinas, v. 56, p. 101-110, 2014.

DURRANT, W. E.; DONG, X. Systemic acquired resistance. Annual Review of Phytopathology, Palo Alto, v. 42, n. 1, p. 185-209, 2004. PMid:15283665. http://dx.doi.org/10.1146/annurev. phyto.42.040803.140421.

FARIAS, A. T. V. Crescimento e desenvolvimento do algodoeiro em função de doses de silício e ácido salicílico. 2012. 63 f. Dissertação (Mestrado)-Centro de Ciências Humanas e Agrárias, Universidade Estadual da Paraíba, Campina Grande, 2012.

GHARIB, F. A. Effect of salicylic acid on the growth, metabolic activities and oil content of basil and marjoram. International Journal of Agriculture and Biology, Pakistan, v. 9, p. 294-301, 2007.

GHASEMZADEH, A.; JAAFAR, H. Z.; KARIMI, E. Involvement of salicylic acid on antioxidant and anticancer properties, anthocyanin production and chalcone synthase activity in ginger (Zingiber officinale Roscoe) varieties. International Journal of Molecular Sciences, Basel, v. 13, n. 11, p. 14828-14844, 2012. PMid:23203096. http://dx.doi.org/10.3390/ijms131114828.

GORNI, P. H.; PACHECO, A. C. Growth promotion and elicitor activity of salicylic acid on Achillea millefolium L. African Journal of Biotechnology, Kenya, v. 15, n. 16, p. 657-665, 2016. http:// dx.doi.org/10.5897/AJB2016.15320.
HAAS, C. J. T.; GONZÁLEZ, G. A.; SAAVEDRA, A. L. Efecto del ácido salicílico en el crecimiento de la raíz y biomasa total de plántulas de trigo. Terra Latinoamericana, Chapingo, v. 33, n. 1, p. 63-68, 2015.

HASHMI, N.; KHAN, M. M. A.; MOINUDDIN; IDREES, M.; AFTAB, T. Exogenous salicylic acid stimulates physiological and biochemical changes to improve growth, yield and active constituents of fennel essential oil. Plant Growth Regulation, The Hague, v. 68, n. 2, p. 281-291, 2012. http://dx.doi.org/10.1007/s10725-012-9716-0. KOVÁCIK, J.; GRUZ, J.; BACKOR, M.; STRNAD, M.; REPCAK, M. Salicylic acid-induced changes to growth and phenolic metabolism in Matricaria chamomilla plants. Plant Cell Reports, Berlin, v. 28, n. 1, p. 134-143, 2009. PMid:18972114. http://dx.doi. org/10.1007/s00299-008-0627-5.

LA CAMERA, S.; GOUZERH, G.; DHONDT, S.; HOFFMANN, L.; FRITIG, B.; LEGRAND, M.; HEITZ, T. Metabolic reprogramming in plant innate immunity: the contributions of phenylpropanoid and oxylipins pathways. Immunological Reviews, Oxford, v. 198, n. 1, p. 267-284, 2004. PMid:15199968. http://dx.doi. org/10.1111/j.0105-2896.2004.0129.x.

LIU, C.; GUO, J.; CUI, Y.; LÜ, T.; ZHANG, X.; SHI, G. Effects of cadmium and salicylic acid on growth, spectral reflectance and photosynthesis of castor bean seedlings. Plant and Soil, The Hague, v. 344, n. 1-2, p. 131-141, 2011. http://dx.doi.org/10.1007/ s11104-011-0733-y.

LORENZI, H.; MATOS, F. J. A. Plantas medicinais do Brasil: nativas e exóticas cultivadas. Nova Odessa: Instituto Plantarum, 2002. 544 p.

MOREIRA, D. L.; LEITÃO, S. G.; GONÇALVES, J. L. S.; WIGG, M. D.; LEITÃO, G. G. Antioxidant and antiviral properties of Pseudopiptadenia contorta (Leguminosae) and of quebracho (Schinopsis sp.) extracts. Química Nova, São Paulo, v. 28, n. 3, p. 421-425, 2005. http://dx.doi.org/10.1590/S010040422005000300011

PARASHAR, A.; YUSUF, M.; FARIDUDDIN, Q.; AHMAD, A. Salicylic acid enhances antioxidant system in Brassica juncea grownunder different levels of manganese. International Journal of Biological Macromolecules, Guildford, v. 70, p. 551-558, 2014. PMid:25036598. http://dx.doi.org/10.1016/j.ijbiomac.2014.07.014.

REIS, M. S.; MARIOT, A.; STEENBOCK, W. Diversidade e domesticação de plantas medicinais. In: SIMÕES, C. M. O.; SCHENKEL, E. P.; GOSMANN, G.; MELLO, J. C. P.; MENTZ, L. A.; PETROVICK, P. R. Farmacognosia: da planta ao medicamento. Porto Alegre: Editora da UFRGS; Florianópolis: Editora da UFSC, 2007. $1104 \mathrm{p}$.

SILVA, F. A. S. Assistat. Versão $\mathbf{7 . 5}$ beta. Campina Grande: Universidade Federal de Campina Grande, 2010.

SILVA, S.; MOREIRA, C. B.; ESQUIBEL, M. A.; GIL, R. A. S. S.; RIEHL, C. A. S.; SATO, A. Effect of salicylic acid on essential 
Increased biomass and salicylic acid elicitor activity in fennel (Foeniculum vulgare Miller)

Gorni, P. H. et al.

oil compounds of Melissa officinalis in vitro plants. Revista Agropecuária Técnica, Paraíba, v. 35, n. 1, p. 178-184, 2014.

SINGLETON, V. L.; ROSSI JUNIOR, J. A. Colorimetry of total phenolics with phosphomolibdic- phosphotungtic acid reagents. American Journal of Enology and Viticulture, Davis, v. 16, n. 3, p. 144-158, 1965.

TAIZ, L.; ZEIGER, E. Fisiologia vegetal. 5. ed. Porto Alegre: Artmed, 2013. 918 p.

VERLAG, D. A. Deutsches Arzneibuch. Stuttgart: Gogi-Verlag $\mathrm{GmBH}, 1978.680 \mathrm{p}$.
VILLANUEVA-COUOH, E.; ALCÁNTAR-GONZÁLEZ, G.; SÁNCHEZGARCÍA, P.; SORIA-FREGOSO, M.; LARQUE-SAAVEDRA, A. Efecto del ácido salicílico y dimetilsulfóxido en la floración de [Chrysanthemum morifolium (Ramat) Kitamura] en Yucatán. Revista Chapingo: Série Horticultura, Chapingo, v. 15, p. 25-31, 2009. YOON, H. K.; MUHAMMAD, H.; ABDUL, L. K.; CHAE, I. N.; SANG, M. K.; HYUN, H. H.; IN JUNG, L. Exogenous application of plant growth regulators increased the total flavonoid content in Taraxacum officinale Wigg. African Journal of Biotechnology, Kenya, v. 8, n. 21, p. 5727-5732, 2009. http://dx.doi.org/10.5897/ AJB09.927. 